\title{
Comprehensive comparison of nutritional constituents and antioxidant activity of cultivated ginseng, mountain-cultivated ginseng, and whole plant parts of mountain-cultivated ginseng
}

\author{
Hee Yul Lee ${ }^{1}$ Jea Gack Jung ${ }^{1}$ Su Cheol Kim ${ }^{1}$ - Du Yong Cho ${ }^{1}$ Min Ju Kim ${ }^{1}$. \\ Ae Ryeon Lee ${ }^{1} \cdot$ Ki-Ho Son ${ }^{2} \cdot$ Jin Hwan Lee ${ }^{3} \cdot$ Dong-Hee Lee $^{4} \cdot$ Kye Man Cho $^{1}$ (D)
}

\section{인삼, 산양삼 및 산양삼 전초의 영양성분 및 항산화 활성의 종합적인 비교}

이희율 ${ }^{1}$ - 정재각 ${ }^{1}$ - 김수철 ${ }^{1}$ - 조두용 ${ }^{1}$ - 김민주 ${ }^{1}$ - 이애련 ${ }^{2}$ 손기호 ${ }^{2}$ - 이진환 ${ }^{2}$. 이동희 ${ }^{4} \cdot$ 조계 만 ${ }^{1}$

Received: 27 September 2021 / Accepted: 3 December 2021 / Published Online: 31 December 2021

(C) The Korean Society for Applied Biological Chemistry 2021

\begin{abstract}
This study investigated that comparison of the nutrients (including fatty acids, amino acids, and minerals) and ginsenoside, total phenolic (TP) and total flavonoid (TF) contents and antioxidant activities in 5-year-old cultivated ginseng (CG), mountain-cultivated ginseng (MCG), and whole plant parts of MCG (WPMCG). The contents of total fatty acids and unsaturated fatty acids were determined highest in MCG (1215.9 and 751.2 $\mathrm{mg} / 100 \mathrm{~g})$, and saturated fatty acid was determined highest in WPMCG (486.4 mg/100 g) respectively. Characteristically, the $\alpha$ linolenic acid content was detected up to 10 times higher in MCG
\end{abstract}

Kye Man Cho $(\bowtie)$

E-mail:kmcho@gnu.ac.kr

${ }^{1}$ Department of Food Science, Gyeongsang National University, Naedongro 139-8, Jinju 52849, Gyeongnam, Republic of Korea

${ }^{2}$ Department of Horticultural Science, Gyeongsang National University, Dongjin-ro 33, Jinju 52725, Gyeongnam, Republic of Korea

${ }^{3}$ Department of Life Resource Industry, Dong-A University, Nakdongdaero 550 beon-gil, Saha-gu, Busan 49315, Republic of Korea

${ }^{4}$ Industry Academy Cooperation Foundation, Andong National University, Andong 36729, Republic of Korea

This is an Open Access article distributed under the terms of the Creative Commons Attribution Non-Commercial License (http://creativecommons. org/licenses/by-nc/3.0/) which permits unrestricted non-commercial use, distribution, and reproduction in any medium, provided the original work is properly cited.
(139.3 mg/100 g) and WPMCG (194.4 mg/100 g) compared to CG $(18.1 \mathrm{mg} / 100 \mathrm{~g})$. Total free and essential amino acid contents were high with $\mathrm{CG}<\mathrm{MCG}<$ WPMCG $(1006.35 \mathrm{mg} / 100 \mathrm{~g}$ and $839.46 \mathrm{mg} / 100 \mathrm{~g})$. Notably, $\gamma$-aminobutyric acid and arginine were detected as the main non-essential amino acids with highest levels detected in WPMCG (163.10 mg/100 g) and MCG (305.23 $\mathrm{mg} / 100 \mathrm{~g})$, respectively. Total mineral content was high in CG $(30.36 \mathrm{mg} / 100 \mathrm{~g})$ and WPMCG $(29.82 \mathrm{mg} / 100 \mathrm{~g})$. Particularly, Calcium (Ca) was detected more than twice as high in WPMCG $(6.68 \mathrm{mg} / 100 \mathrm{~g}$ ) as compared to CG and MCG. TP and TF contents were 5.12 gallic acid $\mathrm{mg} / \mathrm{g}$ and $3.04 \mathrm{RE} \mathrm{mg} / \mathrm{g}$ respectively. Ginsenoside content was the highest in WPMCG (42.44 mg/g) in general and the highest antioxidant activity was also observed in WPMCG.

Keywords Amino acids · Antioxidant $\cdot$ Fatty acids $\cdot$ Ginsenosides Mountain-cultivated ginseng

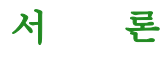

인삼(Panax ginseng C.A. Meyer)은 두릅나무과(Araliaceae) 인 삼속에 속하는 뿌리식물로 동양에서 생약으로 많이 이용되어 왔 다. 인삼은 다시 생육환경에 따라 밭에서 재배한 인삼 $(\mathrm{CG}$, cultivated ginseng), 산에서 인공적으로 재배한 산양삼(MCG, 
mountain-cultivated ginseng) 및 산에서 자연적으로 자란 산삼 (wild ginseng)으로 분류된다[1]. 산양삼이라는 용어는 장뇌삼, 산양산삼 및 산양삼 등으로 불리던 것을 산림청에서 용어를 정 립하고 이를 산양삼으로 사용하도록 규정하였다[2].

산양삼은 특별관리임산물로 지정 및 관리되어 임업 및 산촌 진흥 촉진에 관한법률'에 의하여 재배지 선정, 종묘, 식재, 재배 관리, 품질검사 및 유통 등을 관리하여 인공적인 시설물 설치 없이 자연 상태에서 재배한 한국임업진흥원 품질검사에 합격한 삼을 말한다[3]. 한국, 일본, 중국 등 동아시아와 유럽에서 뿌리 를 식용 또는 약용으로 이용하고 있으며[4], 산양삼은 사포닌계 물질인 ginsenosides와 그 외에 polyacetylenes, phenolics, acidic polysaccharides, peptides, alkaloid, amino acids 유도체[5,6] 등 의 유효성분을 포함하는 것으로 알려져 있다. 현재까지 산양삼 효능은 항산화[7,8], 항암[9], 혈중지질개선, 혈당강하, 항당뇨[10], 항염증[11], 면역 증진[12,13], 간 보호[14] 등이 있는 것으로 알 려져 있으며 재배삼에 비해 약리 효능 및 ginsenosides 함량이 높은 것으로 보고되어 효능 또한 뛰어남을 인정받고 있다[15]. 최근에는 뿌리뿐만 아니라 잎과 줄기에 대한 관심이 증가하여 이에 대한 연구가 이루어지고 있으나 뿌리에 비해 미비한 실정 이며[16], 인삼에 비해 재배가 어렵고 가격이 비싸 대체로 약재 로 이용되고 있어 전반적으로 산양삼에 대한 연구가 미비한 실 정이다[17].

인삼에 존재하는 사포닌인 ginsenosides는 triterpenoid 화합물 로 dammarane과 oleanane으로 구분되며 이중 dammarane은 비 당(aglycone) 부위에 부착된 수산기 $(-\mathrm{OH})$ 의 수에 따라 protopanaxdiol (PPD)계와 protopanaxtriol (PPT)계로 분류되며 $\mathrm{PPD}$ 계는 비당부위의 3 번 및 20번 탄소에, PPT계는 3번, 6번 및 20번 탄소에 수산기가 부착되어 있다. PPD계는 탄소 3 번과 20 번 수산기에, PPT계는 3번 탄소를 제외한 6 번과 20번 탄소 의 수산기에 glucose, arabinose, xylose, rhamnose 등의 당이 결합하여 배당체(glycoside) 구조를 이룬다[18]. Ginsenosides의 기능성으로는 혈당감소[19], 항산화[20], 혈관신생효과[21], 주름 개선[22] 등이 보고되고 있다.

따라서 본 연구를 통해 5 년근의 산양삼 및 산양삼 전초의 지 방산, 아미노산무기질, ginsenosides, 총 phenolics와 총 flavonoids 함량 및 항산화 활성을 비교·분석하였으며 대조구로 5년근 인 삼도 동시에 비교하였다. 특히, 본 연구를 통해 산양삼 전초의 일반식품 또는 가공식품으로 원료 활용화 증대를 위한 기초 자 료를 제공하고자 하였다.

\section{재료 및 방법}

\section{인삼, 산양삼 및 산양삼 전초 원료}

$\mathrm{CG}$ 는 충북 금산군에서 재배된 5 년근을 구입하였고 $\mathrm{MCG}$ 와 산 양삼 전초(WPMCG: whole plant of $\mathrm{MCG}$ )는 경남 함양군에서 재배된 5년근 기준으로 산양삼 뿌리는 4월에 수확한 것을 산양 삼 전초는 6월에 수확한 것을 농업회사법인 진생바이오(Hamyanggun, Gyeongsnagnam-do, Korea)에서 구입하여 사용하였다. 구 입한 시료는 흐르는 물에 세척 후 표면의 물기가 제거되도록 실온에서 2-3시간 음건한 다음 식품 건조기(SI-70S2, Sinil, Daegu, Korea)를 이용하여 $55 \pm 2{ }^{\circ} \mathrm{C}$ 온도로 2-3일간 건조하였다.
건조 후 분쇄기(HGB2WTS3, Waring, Torrington, CT, USA)를 이용하여 분쇄하여 분말을 $-40{ }^{\circ} \mathrm{C}$ 에서 동결 보관하며 시료로 사 용하였다.

\section{시약}

Folin-ciocalteu reagent, diethylen glycol, 2,2-diphenyl-1picrydrazyl (DPPH), 2,2'-azino-bis (3-ethylbenzothiazoline-6sulfonic acid) (ABTS), trichloroacetic acid (TCA), thiobarbituric acid (TBA) 와 2,4,5-tri(2-pyridyl)-1,3,5-triazine (TPTZ) 등은 Sigma-Aldrich Co. (St. Louis, MO, USA)에서 구입하여 사용 하였다. Ginsenoside 표준품 21종 $(\mathrm{Rg} 1, \mathrm{Re}, \mathrm{Ro}, \mathrm{Rf}, \mathrm{F} 5, \mathrm{~F} 3$, Rg2, Rh1, Rb1, Rc, F1, Rb2, Rb3, Rd, Rd2, F2, Rg3, $\mathrm{PPT}$, compound $\mathrm{K}, \mathrm{Rh} 2$ 및 $\mathrm{PPD}$ )는 $\mathrm{KOC}$ biotech (Daejeon, Korea)에서 구입하여 사용하였다. 분석 등에 사용한 high performance liquid chromatography (HPLC) 등급의 유기용매는 J.T.Baker (Philipsbug, NJ, USA)에서 구입하여 사용하였고, 그 외에 사용된 기타 시약은 특급 및 HPLC 등급을 구입하여 사 용하였다.

\section{지방산 분석}

지방산 분석은 Lee 등[23]의 방법에 따라 gas chromatography (GC, Agilent 7890A system, Agilent Technologies Inc., Wilmington, $\mathrm{DE}, \mathrm{USA}$ )를 사용하여 분석하였다. 분석하기에 앞서 시료 $1 \mathrm{~g}$ 에 메탄올에 녹인 $0.5 \mathrm{~N} \mathrm{NaOH} 3 \mathrm{~mL}$ 을 혼합하여 $100{ }^{\circ} \mathrm{C}$ 에서 10 분간 반응하여 지방산과 글리세롤을 가수분해하였다. 이후 반 응물에 삼불화붕소 $\left(\mathrm{BF}_{3}\right) 2 \mathrm{~mL}$ 을 가하여 혼합 후 30 분간 반응 을 통해 메틸에스테르화를 진행하였다. 이어 이소옥탄 $1 \mathrm{~mL}$ 을 가하여 혼합 후 원심분리하여 상층인 이소옥탄층을 회수하여 무 수아황산나트륨과 함께 탈수한 뒤 $0.45 \mu \mathrm{m}$ membrane filter (Dismic-25CS, Toyoroshikaisha Ltd, Tokyo, Japan)로 여과하여 분석하였다. $\mathrm{GC}$ 는 수소 및 질소 가스와 flame ion detector (FID) 및 SP-2560 capillary column $(100 \mathrm{~m} \times 0.25 \mathrm{~mm}$ i.d., $0.25-\mu \mathrm{m}$ film thickness, Sigma-Aldrich Co.)를 사용하였다. 분 석조건은 오븐 온도는 $140{ }^{\circ} \mathrm{C}$ 에서 5 분간 유지 후, $180{ }^{\circ} \mathrm{C}$ 까지 1 분당 $20^{\circ} \mathrm{C}$ 만큼 상승시켜 2 분간 유지하고 최종 $230^{\circ} \mathrm{C}$ 까지 분 당 $5{ }^{\circ} \mathrm{C}$ 만큼 상승시켜 $10 \mu \mathrm{L}$ 의 시료를 주입하여 35 분간 $\mathrm{FID}$ 상 에서 지방산 함량을 검출하였다. Injector의 온도와 FID detector 의 온도는 각각 $220^{\circ} \mathrm{C}$ 와 $240{ }^{\circ} \mathrm{C}$ 로 진행하였다.

\section{유리아미노산 분석}

유리아미노산 분석은 Lee 등[23]의 방법을 일부 변형하여 자동 아미노산 분석기 (L-8900, Hitachi High-Technologies Corp., Tokyo, Japan)를 사용하여 분석하였다. 시료 $0.1 \mathrm{~g}$ 과 HPLC water $5 \mathrm{~mL}$ 를 혼합하여 $60{ }^{\circ} \mathrm{C}$ 에서 1 시간 가수분해하였다. 이어 $10 \% 5$-sulfosalicylic acid를 $1 \mathrm{~mL}$ 첨가해 $4{ }^{\circ} \mathrm{C}$ 에서 2 시간 정치 후 $15,000 \mathrm{rpm}$ 에서 3 분간 원심분리하여 $0.45 \mu \mathrm{m}$-membrane filter로 여과하였다. 이후 여액을 $55{ }^{\circ} \mathrm{C}$ 온도로 감압농축하여 lithium citrate buffer $(\mathrm{pH}$ 2.2) $2 \mathrm{~mL}$ 을 가하여 용해 후 다시 $0.45 \mu \mathrm{m}$-membrane filter로 여과 후 정량 분석하였다.

\section{무기질 분석}

무기질 분석은 식품공정의 무기질 분석법[24]에 준하여 liquid 
chromatography-inductively coupled plasma mass spectrometer (NexION 350 ICP MS, PerkinElmer Inc., Waltham, USA)를 사용하여 분석하였다. 시료 $0.5 \mathrm{~g}$ 에 $70 \%$ 질산 용액 $8 \mathrm{~mL}$ 을 첨 가하여 microwave로 분해 후 멸균 증류수로 최종 $50 \mathrm{~mL}$ 로 정 용하여 시험용액을 조제하였고, 한편 나트륨은 $550-600{ }^{\circ} \mathrm{C}$ 온도 로 회화한 후 $3 \%$ 질산 용액으로 최종 $30 \mathrm{~mL}$ 로 정용해 시험용 액을 제조하여 분석하였다.

\section{Ginsenosides 분석}

Ginsenosides 분석은 기능성식품분석법의 홍삼의 사포닌 분석 방법을 약간 변형하여 HPLC (Agilent 1200 system, Agilent Technologies Inc., Waldbronn, Germany)를 사용하여 분석하였 다. 분석하기에 앞서 시료 $1 \mathrm{~g}$ 에 $70 \% \mathrm{MeOH} 20 \mathrm{~mL}$ 을 가하여 $70{ }^{\circ} \mathrm{C}$ 항온수조에서 1 시간 추출과 원심분리를 2 회 반복하여 획 득한 약 $40 \mathrm{~mL}$ 추출물을 $0.45 \mu \mathrm{m}$-membrane filter로 여과하여 $55-60{ }^{\circ} \mathrm{C}$ 온도로 감압 농축하였다. 이어 농축물은 $\mathrm{HPLC}$ water $2 \mathrm{~mL}$ 에 녹여 $0.45 \mu \mathrm{m}$-membrane filter로 여과 후 분석 시료로 사용하였다. 분석에 사용된 column은 TSKgel ODS-100Z (4.6 $\times 250 \mathrm{~nm}, 5 \mu \mathrm{m}$, Tosoh Corp.,)이며 이동상 용매는 HPLC 등급 의 water (용매 A)와 acetonitrile (용매 B)를 사용하였다. 분석 의 자세한 조건은 용매 $\mathrm{A}$ 를 기준으로 $81 \%-10$ 분, $80 \%-15$ 분, $77 \%-40$ 분, $70 \%-42$ 분, $65 \%-75$ 분, $30 \%-80$ 분, $10 \%-90$ 분 및 $10 \%-100$ 분으로 유속은 $1 \mathrm{~mL} / \mathrm{min}$ 로 diode array detector 통과 하여 $203 \mathrm{~nm}$ 에서 분석하였다. 분석 column의 온도는 $30{ }^{\circ} \mathrm{C}$ 를 유지하였고 시료 주입량은 $10 \mu \mathrm{L}$ 를 주입하였다.

\section{추출물 제조}

시료 $1 \mathrm{~g}$ 와 $50 \%$ 주정 $20 \mathrm{~mL}$ 혼합하여 실온에서 12-14시간 추 출한다. 이어 $15,000 \mathrm{rpm}$ 에서 15 분간 원심분리하고 상등액을 $0.45 \mu \mathrm{m}$-membrane filter로 여과 후 총 phenolics, 총 flavonoids 및 항산화 활성 측정 시료로 사용하였다.

\section{총 phenolics 및 총 flavonoids 분석}

총 phenolics 함량은 Folin Denis법[25]에 준하여 측정하였다. 제조한 추출물 $0.5 \mathrm{~mL}$ 과 $25 \% \quad \mathrm{Na}_{2} \mathrm{CO}_{3} \quad 0.5 \mathrm{~mL}$ 을 시험관에 가 하여 3 분간 반응한다. 이어 Folin-ciocalteu phenol 시약 0.25 $\mathrm{mL}$ 을 가하여 $30^{\circ} \mathrm{C}$ 온도로 1 시간 반응시켜 분광 광도계(UV1800 240V, Shimadzu Corp., Kyoto, Japan)를 이용하여 750 $\mathrm{nm}$ 로 흡광도 값을 측정하였다. 함량은 gallic acid (GAE)로 작 성한 표준곡선을 이용해 구하였다.

총 flavonoids 함량은 Park 등[26]의 방법을 변형하여 측정하 였다. 제조한 추출물 $0.5 \mathrm{~mL}$, diethylene glycol $1 \mathrm{~mL}$ 및 $1 \mathrm{~N}$ $\mathrm{NaOH} 0.01 \mathrm{~mL}$ 을 시험관에 분주하여 $37^{\circ} \mathrm{C}$ 온도로 항온수조에 서 1 시간 반응시켜 분광 광도계를 이용하여 $420 \mathrm{~nm}$ 로 흡광도 값을 측정하였다. 함량은 rutin (RE)으로 작성한 표준곡선을 이 용해 구하였다.

\section{항산화 활성}

$\mathrm{DPPH}$ 라디칼 소거활성은 Hwang 등[27]의 방법에 준하여 측정 하였다. $\mathrm{DPPH}$ 용액 $\left(1.5 \times 10^{-4} \mathrm{M}\right) \quad 0.8 \mathrm{~mL}$ 과 추출액 $0.2 \mathrm{~mL}$ 를 시험관에 분주하여 암실에서 30 분 반응 후 분광 광도계를 이용 해 $525 \mathrm{~nm}$ 에서 흡광도 값을 측정하였다. 음성 대조구는 시료
대신에 추출용매를 사용하였다.

$\mathrm{ABTS}$ 라디칼 소거활성은 $7 \mathrm{mM} \mathrm{ABTS}$ 용액과 $2.45 \mathrm{mM}$ potassium persulphate를 1:1로 혼합하여 12-16시간 동안 $\mathrm{ABTS}$ 양이온이 형성되도록 암실에서 방치하였다. 이 $\mathrm{ABTS}$ 용액을 메탄올을 이용해 $732 \mathrm{~nm}$ 에서 흡광도 값이 $0.7 \pm 0.02$ 가 되도록 희석하여 $\mathrm{ABTS}+$ 용액을 제조하여 실험에 사용하였다. $\mathrm{ATBS}^{+}$ 용액 $0.9 \mathrm{~mL}$ 과 추출물 $0.1 \mathrm{~mL}$ 을 시험관에 가하여 3 분간 반응 후 분광 광도계를 이용해 $732 \mathrm{~nm}$ 에서 흡광도 값을 측정하였다 [27]. 음성 대조구는 시료 대신에 추출용매를 사용하였다.

Hydroxyl 라디칼 소거활성은 Hwang 등[27]의 방법에 준하여 측정하였다. 시험관에 시료 추출물 $1.2 \mathrm{~mL}, 10 \mathrm{mM} \mathrm{FeSO}$. $7 \mathrm{H}_{2} \mathrm{O}$-EDTA 용액 $0.2 \mathrm{~mL}, 10 \mathrm{mM}$ 2-deoxylribose $0.2 \mathrm{~mL}$ 과 $10 \mathrm{mM} \mathrm{H} \mathrm{O}_{2} \quad 0.4 \mathrm{~mL}$ 를 가하고 $37^{\circ} \mathrm{C}$ 에서 4 시간 반응하였다. 반 응 후 이에 HPLC water에 용해시킨 $1 \% \mathrm{TBA}$ 와 $2.8 \% \mathrm{TCA}$ 를 각각 $1 \mathrm{~mL}$ 씩 가하여 $100{ }^{\circ} \mathrm{C}$ 에서 20 분간 가온하였다. 발색된 반응물을 냉각 후 분광 광도계를 이용하여 $525 \mathrm{~nm}$ 로 흡광도 값 을 측정하였다. 음성대조구는 시료 추출물 대신 PBS 용액을 취 하여 실험하였다. 한편 모든 라디칼 소거 활성은 실험구와 음 성대조구의 흡광도 차이를 백분율 $(\%)$ 로 산출하였다.

\section{라디칼 소거 활성 $(\%)$ \\ $=[1-($ 실험구 흡광도 값/음성대조구 흡광도 값 $)] \times 100$}

FRAP 환원력 측정은 Lee 등[23]준하여 실험하였다. $30 \mathrm{mM}$ acetate buffer $(\mathrm{pH} 3.6), 40 \mathrm{mM} \mathrm{HCl}$ 에 용해시킨 $10 \mathrm{mM}$ $\mathrm{TPTZ}$ 시약, 및 증류수에 용해시킨 $20 \mathrm{mM} \mathrm{FeCl}$ 용액을 $10: 1: 1 \quad(\mathrm{v} / \mathrm{v} / \mathrm{v})$ 의 비율로 혼합하여 $37^{\circ} \mathrm{C}$ 에서 15 분 반응하여 FRAP 측정 시약을 조제하였다. 시료 $50 \mu \mathrm{L}$ 와 예비 반응시킨 FRAP 시약 $950 \mu \mathrm{L}$ 를 시험관에 분주하여 $37^{\circ} \mathrm{C}$ 에서 15 분 반응 시키고 분광 광도계를 이용하여 $590 \mathrm{~nm}$ 에서 흡광도 값을 측정 하였다. 음성대조구 실험은 시료대신에 추출용매를 사용하였다.

\section{통계분석}

통계처리 실험 결과는 SPSS 12.0 package를 사용하여 분산 분 석을 수행하였고 평균 \pm 표준편차로 나타내었다.

\section{결과 및 고찰}

\section{CG, MCG 및 WPMCG의 지방산 함량}

$\mathrm{CG}, \mathrm{MCG}$ 및 $\mathrm{WPMCG}$ 의 지방산 함량을 비교한 결과 Table 1 와 같았다. 총 지방산 함량은 $\mathrm{MCG}(1215.9 \mathrm{mg} / 100 \mathrm{~g})$ 에서 가 장 높게 검출되었으며 $\mathrm{CG} \quad(863.6 \mathrm{mg} / 100 \mathrm{~g})$ 와 $\mathrm{WPMCG}$ $(1126.6 \mathrm{mg} / 100 \mathrm{~g})$ 는 상대적으로 낮은 함량이 검출되었다. 포화 지방산 중 palmitic acid가 주요 물질로 검출되었으며 $\mathrm{CG}$, $\mathrm{MCG}$ 및 $\mathrm{WPMCG}$ 각각 $227.9,265.0$ 및 $338.7 \mathrm{mg} / 100 \mathrm{~g}$ 로 $\mathrm{WPMCG}$ 에서 가장 높게 검출되었다. Arachidic acid와 lignoceric acid는 $\mathrm{MCG}$ 에서 $14.0 \mathrm{mg} / 100 \mathrm{~g}$ 과 $12.5 \mathrm{mg} / 100 \mathrm{~g}$ 이며 WPMCG 에서 $10.9 \mathrm{mg} / 100 \mathrm{~g}$ 과 $21.5 \mathrm{mg} / 100 \mathrm{~g}$ 으로 검출되었고 한편 $\mathrm{CG}$ 에서는 검출되지 않았다. Linoleic acid는 주요 불포화 지방산으 로 검출되었으며 $\mathrm{MCG}(392.4 \mathrm{mg} / 100 \mathrm{~g})$ 에서 가장 높은 함량을 나타내었다. 특징적으로 $\alpha$-linolenic acid 함량은 CG (18.1 mg/ $100 \mathrm{~g})$ 과 비교하여 $\mathrm{MCG}(139.3 \mathrm{mg} / 100 \mathrm{~g})$ 및 WPMCG (194.4 
Table 1 Comparison of fatty acid contents on cultivated ginseng, mountain-cultivated ginseng, and whole plant of mountain-cultivated ginseng

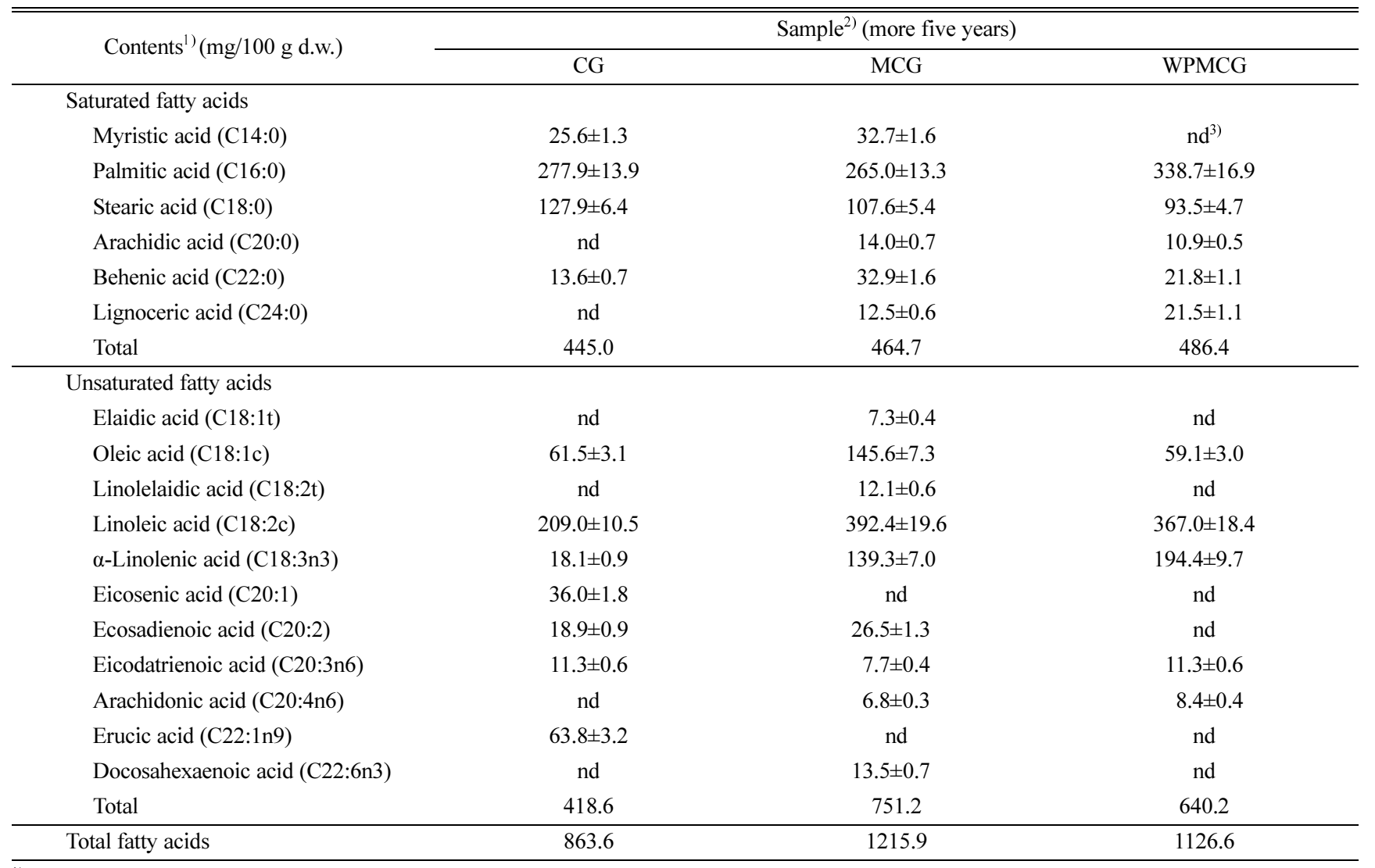

${ }^{1)}$ All values are presented as the mean \pm SD of triplicate determination

${ }^{2}$ Sample: CG, cultivated ginseng; MCG, mountain-cultivated ginseng; and WPMCG, whole plant of mountain-cultivated ginseng

${ }^{3)}$ nd: not detected

$\mathrm{mg} / 100 \mathrm{~g}$ )에서 많게는 10 배 이상 높게 검출되었다.

Park 등[28]은 고려인삼에서 palmitic acid, oleic acid 및 linolenic acid를 주요 지방산으로 보고하였으며, 장뇌삼 부위별 지방산 분석결과 잎과 줄기는 linoleic acid, palmitic acid 및 oleic acid를, 뿌리는 linoleic acid, oleic acid 및 stearic acid를 주요 지방산으로 함유한다고 보고되었다[29]. Ko와 Chung[30] 은 인삼 뿌리 지방산 분석결과 linoleic acid $46.62 \%$, palmitic acid $29.85 \%$ 및 oleic acid $12.31 \%$ 함유하는 것으로 보고해 기 존 연구결과에서 palmitic acid, linoleic acid 및 palmitic acid 가 공통적으로 인삼의 주된 지방산으로 보고되었으며 본 연구 또한 이와 유사하였다. 반면 본 연구의 $\alpha$-linolenic acid 함량은 인삼과 비교해 $\mathrm{MCG}$ 및 $\mathrm{WPMCG}$ 에서 다량 검출되어 $\alpha$ linolenic acid 함량은 부위와의 상관성 보다 삼 종류 차이에 기 인한 것으로 판단된다. 한편 뿌리와 비교하여 잎과 줄기에서 palmitic acid 비율이 비교적 높게 보고되어 있으며[29], 본 연 구에서 잎과 줄기를 포함한 $\mathrm{WPMCG}$ 에서 $\mathrm{CG}$ 및 $\mathrm{MCG}$ 와 비 교해 palmitic acid 함량이 높은 것으로 확인되었다. 따라서 WPMCG의 palmitic acid 함량은 잎과 줄기에 기인한 것으로 판단된다.

\section{CG, MCG 및 WPMCG의 유리아미노산 함량}

$\mathrm{CG}, \mathrm{MCG}$ 및 $\mathrm{WPMCG}$ 의 유리아미노산 함량을 비교한 결과
Table 2과 같았다. 총 유리아미노산 함량은 WPMCG (1006.35) $>\mathrm{MCG}$ (674.71)> CG $(627.62 \mathrm{mg} / 100 \mathrm{~g})$ 순으로 높은 함량을 나타내었고 비필수 아미노산 함량 또한 WPMCG (839.46)> MCG (569.07) > CG $(450.43 \mathrm{mg} / 100 \mathrm{~g})$ 순으로 확인되었다. 주 된 비필수 아미노산으로는 $\gamma$-aminobutyric acid와 arginine이 검 출되었으며 이중 $\gamma$-aminobutyric acid는 CG $(83.91 \mathrm{mg} / 100 \mathrm{~g})$ 및 $\mathrm{MCG}(80.26 \mathrm{mg} / 100 \mathrm{~g})$ 와 비교해 WPMCG $(163.10 \mathrm{mg} / 100 \mathrm{~g})$ 에서 2배 이상 높은 함량이 검출되었다. Arginine 함량은 CG $(90.59 \mathrm{mg} / 100 \mathrm{~g})$ 와 비교하여 $\mathrm{MCG}(305.23 \mathrm{mg} / 100 \mathrm{~g})$ 와 WPMCG $(297.13 \mathrm{mg} / 100 \mathrm{~g})$ 에서 약 3 배 높게 검출되었다. $\gamma$-Aminobutyric acid 전구물질인 glutamic acid 함량 역시 WPMCG (37.71)> MCG (27.48)> CG $(13.46 \mathrm{mg} / 100 \mathrm{~g})$ 순으로 확인되었다. 비필 수 아미노산과 달리 필수 아미노산 함량의 경우 CG (177.19 $\mathrm{mg} / 100 \mathrm{~g}$ )에서 가장 높은 함량을 보였으며 다음으로 WPMCG $(166.89 \mathrm{mg} / 100 \mathrm{~g})$ 와 $\mathrm{MCG}(105.64 \mathrm{mg} / 100 \mathrm{~g})$ 순으로 확인되었 다. 필수 아미노산은 대부분 $\mathrm{CG}$ 에서 가장 높은 함량을 보였으 나, threonine 및 histidine은 WPMCG (30.37 및 $16.64 \mathrm{mg} / 100 \mathrm{~g}$ ) 에서 비교적 높게 검출되었다.

Choi와 $\mathrm{Oh}[31]$ 은 한국 인삼에서 arginine $>$ lysine $>$ alanine $>$ aspartic acid $>$ serine순으로 아미노산 함량이 검출된 것으로 보 고하였으며, Ko 등[32]은 인삼속에는 arginine을 아미노산 중 가 장 많이 함유 하는 것으로 보고하였다. Kang 등[33]의 연구에 
Table 2 Comparison of free amino acid contents on cultivated ginseng, mountain-cultivated ginseng, and whole plant of mountain-cultivated ginseng

\begin{tabular}{|c|c|c|c|}
\hline \multirow{2}{*}{ Contents $^{1)}(\mathrm{mg} / 100 \mathrm{~g}$ d.w. $)$} & \multicolumn{3}{|c|}{ Sample $^{2)}$ (more five years) } \\
\hline & $\mathrm{CG}$ & MCG & WPMCG \\
\hline \multicolumn{4}{|l|}{ Non-essential amino acids } \\
\hline Proline & $18.93 \pm 0.95$ & $22.01 \pm 1.10$ & $19.80 \pm 0.99$ \\
\hline Aspartic acid & $36.31 \pm 1.82$ & $\mathrm{nd}^{3)}$ & $61.09 \pm 3.05$ \\
\hline Serine & $26.97 \pm 1.35$ & $14.24 \pm 0.71$ & $28.23 \pm 1.41$ \\
\hline Aspartic acid - $\mathrm{NH}_{2}$ & $34.80 \pm 1.74$ & $16.04 \pm 0.80$ & $95.75 \pm 4.79$ \\
\hline Glutamic acid & $13.46 \pm 0.67$ & $27.48 \pm 1.37$ & $37.71 \pm 1.89$ \\
\hline Sarcosine & nd & nd & $2.73 \pm 0.14$ \\
\hline Aminoadipic acid & $1.53 \pm 0.08$ & $0.85 \pm$ & $1.24 \pm 0.06$ \\
\hline Glycine & $6.51 \pm 0.33$ & $6.15 \pm 0.31$ & $6.37 \pm 0.32$ \\
\hline Alanine & $51.33 \pm 2.57$ & $40.35 \pm 2.02$ & $42.65 \pm 2.13$ \\
\hline Citrulline & nd & $3.15 \pm 0.16$ & $2.79 \pm 0.14$ \\
\hline$\alpha$-aminobutyric acid & $13.76 \pm 0.69$ & $2.68 \pm 0.13$ & $6.23 \pm 0.31$ \\
\hline Cystine & $20.99 \pm 1.05$ & $16.96 \pm 0.85$ & $19.82 \pm 0.99$ \\
\hline Cystathionine & $10.27 \pm 0.51$ & nd & nd \\
\hline Tyrosine & $16.69 \pm 0.83$ & $10.28 \pm 0.51$ & $21.28 \pm 1.06$ \\
\hline$\beta$-alanine & $7.92 \pm 0.40$ & $5.01 \pm 0.25$ & $10.06 \pm 0.50$ \\
\hline$\beta$-aminoisobutyric acid & $4.18 \pm 0.21$ & $3.22 \pm 0.16$ & $6.19 \pm 0.31$ \\
\hline$\gamma$-aminobutyric acid & $83.91 \pm 4.20$ & $80.26 \pm 4.01$ & $163.10 \pm 8.16$ \\
\hline Aminoethanol & $6.71 \pm 0.34$ & $8.87 \pm 0.44$ & $7.04 \pm 0.35$ \\
\hline Hydroxyproline & $1.58 \pm 0.08$ & $1.49 \pm 0.07$ & $1.42 \pm 0.07$ \\
\hline Ornithine & $3.99 \pm 0.20$ & $4.57 \pm 0.23$ & $7.68 \pm 0.38$ \\
\hline 1-Methylhistidine & nd & $0.23 \pm 0.01$ & $0.67 \pm 0.03$ \\
\hline 3-Methylhistidine & nd & nd & $0.48 \pm 0.02$ \\
\hline Arginine & $90.59 \pm 4.53$ & $305.23 \pm 15.26$ & $297.13 \pm 14.86$ \\
\hline Total & 450.43 & 569.07 & 839.46 \\
\hline \multicolumn{4}{|l|}{ Essential amino acids } \\
\hline Threonine & $21.06 \pm 1.05$ & $11.60 \pm 0.58$ & $30.37 \pm 1.52$ \\
\hline Valine & $30.27 \pm 1.51$ & $15.31 \pm 0.77$ & $15.12 \pm 0.76$ \\
\hline Methionine & $4.36 \pm 0.22$ & $7.30 \pm 0.37$ & $15.73 \pm 0.79$ \\
\hline Isoleucine & $25.50 \pm 1.28$ & $13.65 \pm 0.68$ & $15.65 \pm 0.78$ \\
\hline Leucine & $35.97 \pm 1.80$ & $20.53 \pm 1.03$ & $22.32 \pm 1.12$ \\
\hline Phenylalanine & $24.56 \pm 1.23$ & $12.33 \pm 0.62$ & $21.75 \pm 1.09$ \\
\hline Lysine & $28.32 \pm 1.42$ & $16.56 \pm 0.83$ & $29.31 \pm 1.47$ \\
\hline Histidine & $7.15 \pm 0.36$ & $8.36 \pm 0.42$ & $16.64 \pm 0.83$ \\
\hline Total & $177.19 \pm 8.86$ & $105.64 \pm 5.28$ & $166.89 \pm 8.34$ \\
\hline Total amino acids & 627.62 & 674.71 & 1006.35 \\
\hline Ammonia & $9.85 \pm 0.49$ & $13.30 \pm 0.67$ & $15.46 \pm 0.77$ \\
\hline
\end{tabular}

${ }^{15}$ All values are presented as the mean $\pm \mathrm{SD}$ of triplicate determination

${ }^{2}$ Sample: CG, cultivated ginseng; MCG, mountain-cultivated ginseng; and WPMCG, whole plant of mountain-cultivated ginseng

${ }^{3)}$ nd: not detected

따르면 산양삼의 아미노산은 arginine $>$ asparagine $>\gamma$-aminobutyric acid $>$ glutamine $>$ alanine $>$ aspartic acid 순으로 높은 함량을 나타낸다고 보고하여, 본 연구결과 $\mathrm{CG}, \mathrm{MCG}$ 및 WPMCG의 arginine 함량과 유사한 결과를 보여 인삼류에는 아 미노산 중 arginine 함량이 가장 높은 것으로 확인되었으며 $\mathrm{CG}$ 에 비해 $\mathrm{MCG}$ 와 $\mathrm{WPMCG}$ 에서 더 많은 함량을 가지는 것으로
확인되었다. Arginine은 생장호르몬의 분비를 촉진하고, 생체내 에서 여러 생리조절에 관여하는 nitric oxide를 합성하는 효소의 기질로 이용되어 arginine을 다량 함유한 산양삼은 arginine 공 급원이 될 수 있을 것으로 예상된다. $\mathrm{Kim}$ 과 $\mathrm{Kim}[29$ ]은 장뇌삼 은 뿌리에 비해 잎에서 aspartic acid, L-sarcosine, $\beta$-alanine 및 $\gamma$-aminobutyric acid 함량이 높은 것으로 보고하였으며, 줄기는 
Table 3 Comparison of mineral contents on cultivated ginseng, mountain-cultivated ginseng, and whole plant of mountain-cultivated ginseng

\begin{tabular}{|c|c|c|c|}
\hline \multirow{2}{*}{ Contents $^{1)}$ (mg/100 g d.w.) } & \multicolumn{3}{|c|}{ Sample $^{2)}$ (more five years) } \\
\hline & $\mathrm{CG}$ & $\mathrm{MCG}$ & WPMCG \\
\hline Phosphorus (P) & $4.48 \pm 0.22$ & $1.63 \pm 0.08$ & $1.99 \pm 0.10$ \\
\hline Sulfur (S) & $1.82 \pm 0.09$ & $0.98 \pm 0.05$ & $1.19 \pm 0.06$ \\
\hline Kalium (K) & $17.79 \pm 0.89$ & $8.75 \pm 0.44$ & $16.43 \pm 0.82$ \\
\hline Calcium (Ca) & $3.35 \pm 0.17$ & $2.99 \pm 0.15$ & $6.68 \pm 0.33$ \\
\hline Magnesium (Mg) & $1.97 \pm 0.10$ & $1.60 \pm 0.08$ & $2.15 \pm 0.11$ \\
\hline Iron $(\mathrm{Fe})$ & $0.04 \pm 0.00$ & $0.21 \pm 0.01$ & $0.20 \pm 0.01$ \\
\hline Zinc $(\mathrm{Zn})$ & $0.02 \pm 0.00$ & $0.01 \pm .0 .00$ & $0.02 \pm 0.00$ \\
\hline Manganese (Mn) & $0.02 \pm 0.00$ & $0.03 \pm 0.00$ & $0.06 \pm 0.00$ \\
\hline Aluminium (Al) & $0.09 \pm 0.00$ & $0.41 \pm 0.02$ & $0.38 \pm 0.02$ \\
\hline Boron (B) & $0.10 \pm 0.01$ & $0.07 \pm 0.00$ & $0.06 \pm 0.00$ \\
\hline Silicon $(\mathrm{Si})$ & $0.67 \pm 0.03$ & $0.70 \pm 0.04$ & $0.66 \pm 0.03$ \\
\hline Sodium $(\mathrm{Na})$ & $0.01 \pm 0.00$ & $0.01 \pm 0.00$ & nd \\
\hline Total & 30.36 & 17.39 & 29.82 \\
\hline
\end{tabular}

${ }^{1)}$ All values are presented as the mean \pm SD of triplicate determination

${ }^{2}$ Sample: CG, cultivated ginseng; MCG, mountain-cultivated ginseng; and WPMCG, whole plant of mountain-cultivated ginseng

L-sarcosine, $\beta$-alanine 및 $\gamma$-aminobutyric acid 함량이 높은 것 으로 보고하여 본 연구의 잎, 줄기를 포함한 $\mathrm{WPMCG}$ 의 아미 노산 구성이 이와 유사하게 확인되었다.

\section{CG, MCG 및 WPMCG의 무기질 함량}

$\mathrm{CG}, \mathrm{MCG}$ 및 $\mathrm{WPMCG}$ 의 무기질 함량을 비교한 결과 Table 3 와 같았다. 총 무기질 함량은 $\mathrm{MCG}(19.39 \mathrm{mg} / 100 \mathrm{~g})$ 에 비해 $\mathrm{CG}(30.36 \mathrm{mg} / 100 \mathrm{~g})$ 와 WPMCG $(29.82 \mathrm{mg} / 100 \mathrm{~g})$ 에서 약 2배 높게 검출되었으며, 이 중 칼륨 $(\mathrm{K})$ 함량은 $\mathrm{CG}(17.79 \mathrm{mg} / 100 \mathrm{~g})$, MCG $(8.75 \mathrm{mg} / 100 \mathrm{~g})$ 및 WPMCG $(16.43 \mathrm{mg} / 100 \mathrm{~g})$ 의 총 무 기질 함량의 약 $50 \%$ 이상을 차지하는 것으로 확인되었다. 인 (P) 함량은 MCG $(1.63 \mathrm{mg} / 100 \mathrm{~g})$ 및 WPMCG $(1.99 \mathrm{mg} / 100 \mathrm{~g})$ 와 비교해 $\mathrm{CG}(4.48 \mathrm{mg} / 100 \mathrm{~g})$ 에서 높은 함량이 검출되었고, 칼 슘 $(\mathrm{Ca})$ 은 $\mathrm{CG}(3.35 \mathrm{mg} / 100 \mathrm{~g})$ 및 $\mathrm{MCG}(2.99 \mathrm{mg} / 100 \mathrm{~g})$ 와 비 교하여 WPMCG $(6.68 \mathrm{mg} / 100 \mathrm{~g})$ 에서 높게 검출되었다.

$\mathrm{Ko}$ 등[32]은 인삼류에 분석한 10 종의 무기질 중 비교적 $\mathrm{N}$ 과 $\mathrm{K}$ 이 많은 것으로 보고하였으며, Lee 등[34]은 한국인삼의 무기 질 함량은 $\mathrm{K}>\mathrm{Ca}>\mathrm{Na}>\mathrm{Fe}>\mathrm{Mn}$ 순으로 나타내는 것으로 보 고하였다. $\mathrm{Han}$ 등[35]은 인삼의 잎과 줄기의 무기질 함량은 $\mathrm{K}$, $\mathrm{Ca}, \mathrm{Mg}, \mathrm{Na}$ 및 $\mathrm{P}$ 순으로 보고하였고 그 밖에 $\mathrm{Fe}, \mathrm{Cu}, \mathrm{Mn}$ 및 $\mathrm{P}$ 등을 소량 함유하는 것으로 보고하여 본 연구의 $\mathrm{WPMCG}$ 의 무기질 구성 비율과 비슷하게 확인되었다. 본 연구의 $\mathrm{CG}, \mathrm{MCG}$ 및 $\mathrm{WPMCG}$ 는 기존의 인삼과 마찬가지로 $\mathrm{K}$ 이 가장 높게 검출 되었으며 $\mathrm{K}$ 은 체내 $\mathrm{Na}$ 균형을 조절하여 혈압을 유지함으로 이 를 섭취함에 따라 $\mathrm{K}$ 의 기능을 가질 수 있을 것으로 판단된다 [36].

\section{CG, MCG 및 WPMCG의 총 phenolics 및 총 flavonoids 함량}

$\mathrm{CG}, \mathrm{MCG}$ 및 $\mathrm{WPMCG}$ 의 총 phenolics 및 총 flavonoids 함량 을 비교한 결과 Fig. 1과 같았다. 총 phenolics 함량은 $\mathrm{CG}$ $(2.26 \mathrm{GAE} \mathrm{mg} / \mathrm{g})$ 과 비교하여 $\mathrm{MCG}(2.57 \mathrm{GAE} \mathrm{mg} / \mathrm{g})$ 에서 미
(A)

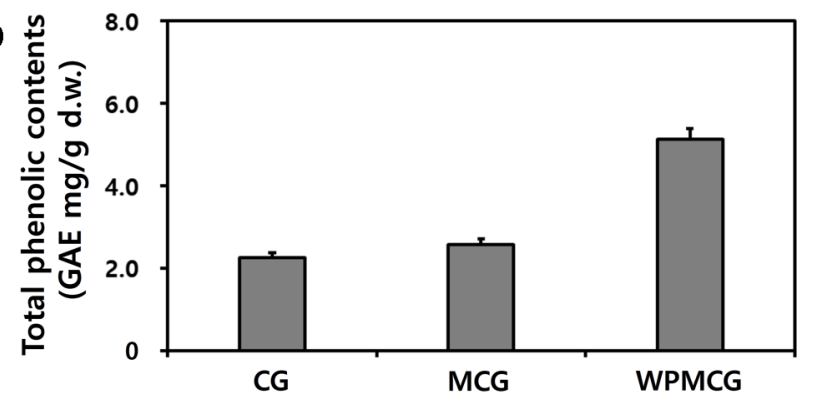

(B)

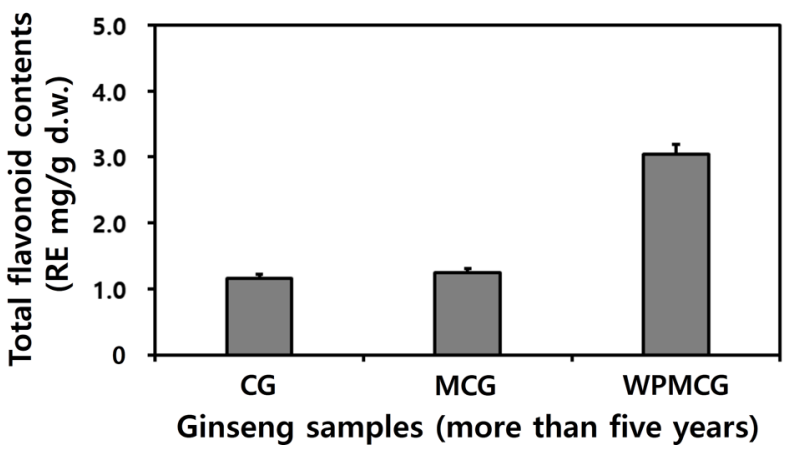

Fig. 1 Comparison of total phenolic and total flavonoid contents on cultivated ginseng, mountain-cultivated ginseng, and whole plant of mountain-cultivated ginseng. (A) Total phenolic contents; and (B) total flavonoid contents. All values are present as the mean \pm SD of triplicate determination

량 높게 검출되었으나, WPMCG $(5.12 \mathrm{GAE} \mathrm{mg/g}$ )는 약 2 배 이상 높게 검출되었다. 총 flavonoids 함량은 $\mathrm{CG}$ (1.16 RE $\mathrm{mg} / \mathrm{g}$ )과 $\mathrm{MCG}(1.25 \mathrm{RE} \mathrm{mg} / \mathrm{g})$ 은 비슷한 수준이었으나, 이에 비해 WPMCG (3.04 RE mg/g)는 약 2.4-2.6배의 함량을 나타 내었다.

$\operatorname{Park}[39]$ 은 새싹삼 잎과 뿌리의 총 phenolics 함량은 4.83과 
Table 4 Comparison of ginsenoside contents on cultivated ginseng, mountain-cultivated ginseng, and whole plant of mountain-cultivated ginseng

\begin{tabular}{|c|c|c|c|}
\hline \multirow{2}{*}{ Contents $^{1)}$ (mg/g d.w.) } & \multicolumn{3}{|c|}{ Sample $^{2)}$ (more five years) } \\
\hline & $\mathrm{CG}$ & MCG & WPMCG \\
\hline \multicolumn{4}{|l|}{ Protopanaxtriol types } \\
\hline Ginsenoside $\operatorname{Rg} 1$ (1) & $3.25 \pm 0.16$ & $1.45 \pm 0.07$ & $2.96 \pm 0.15$ \\
\hline Ginsenoside Re (2) & $1.78 \pm 0.09$ & $2.53 \pm 0.13$ & $7.78 \pm 0.39$ \\
\hline Ginsenoside Rf (4) & $0.72 \pm 0.04$ & $0.59 \pm 0.03$ & $0.44 \pm 0.02$ \\
\hline Ginsenoside F5 (5) & $\mathrm{nd}^{3)}$ & nd & $0.61 \pm 0.03$ \\
\hline Ginsenoside F3 (6) & nd & nd & $2.07 \pm 0.10$ \\
\hline Ginsenoside $\operatorname{Rg} 2$ (7) & $0.22 \pm 0.01$ & $0.59 \pm 0.03$ & $1.06 \pm 0.05$ \\
\hline Ginsenoside Rh1 (8) & $0.19 \pm 0.01$ & $0.34 \pm 0.02$ & $0.12 \pm 0.01$ \\
\hline Ginsenoside F1 (11) & nd & nd & $0.74 \pm 0.04$ \\
\hline Protopanaxtriol (18) & $0.33 \pm 0.02$ & $0.35 \pm 0.02$ & $0.62 \pm 0.03$ \\
\hline Total & 6.49 & 5.85 & 16.4 \\
\hline \multicolumn{4}{|l|}{ Protopanaxdiol types } \\
\hline Ginsenoside Rb1 (9) & $3.29 \pm 0.16$ & $3.55 \pm 0.18$ & $4.03 \pm 0.20$ \\
\hline Ginsenoside Rc (10) & $0.78 \pm 0.04$ & $1.56 \pm 0.08$ & $2.85 \pm 0.14$ \\
\hline Ginsenoside Rb2 (12) & $0.28 \pm 0.01$ & $0.52 \pm 0.03$ & $1.81 \pm 0.09$ \\
\hline Ginsenoside Rb3 (13) & nd & $0.58 \pm 0.03$ & $0.32 \pm 0.02$ \\
\hline Ginsenoside Rd (14) & nd & nd & $4.84 \pm 0.24$ \\
\hline Ginsenoside Rd2 (15) & $0.15 \pm 0.01$ & $1.36 \pm 0.07$ & $3.78 \pm 0.19$ \\
\hline Ginsenoside F2 (16) & $0.23 \pm 0.01$ & $0.25 \pm 0.01$ & $4.01 \pm 0.20$ \\
\hline Ginsenoside Rg3 (17) & $0.08 \pm 0.00$ & $0.17 \pm 0.01$ & $0.56 \pm 0.03$ \\
\hline Compound K (19) & $0.29 \pm 0.01$ & $0.29 \pm 0.01$ & $0.55 \pm 0.03$ \\
\hline Ginsenoside Rh2 (20) & nd & nd & $0.24 \pm 0.01$ \\
\hline Protopanaxdiol (21) & $0.99 \pm 0.05$ & $0.51 \pm 0.03$ & $0.92 \pm 0.05$ \\
\hline Total & 6.09 & 8.79 & 23.91 \\
\hline \multicolumn{4}{|l|}{ Oleanane types } \\
\hline Ginsenoside Ro (3) & $1.73 \pm 0.09$ & $3.37 \pm 0.17$ & $2.13 \pm 0.11$ \\
\hline Total & 1.73 & 3.37 & 2.13 \\
\hline Total ginsenosides & 14.31 & 18.01 & 42.44 \\
\hline
\end{tabular}

\footnotetext{
${ }^{1)}$ All values are presented as the mean $\pm \mathrm{SD}$ of triplicate determination
}

${ }^{2}$ Sample: CG, cultivated ginseng; MCG, mountain-cultivated ginseng; and WPMCG, whole plant of mountain-cultivated ginseng

${ }^{3)}$ nd: not detected

$4.00 \mathrm{GAE} \mathrm{mg} / \mathrm{g}$ 이며, 총 flavonoids 함량은 6.04 과 $4.92 \mathrm{RE}$ $\mathrm{mg} / \mathrm{g}$ 으로 보고하였다. Kim 등[38]은 새싹인삼의 지하부(뿌리)에 비해 지상부(잎, 줄기)의 총 phenolics 및 flavonoids 함량이 모 두 높은 것으로 보고하였다. 이러한 선행 연구결과를 통해 본 연구의 WPMCG에서 총 phenolics 및 총 flavonoids 함량이 높 았던 것은 잎과 줄기에 기인 것으로 판단된다.

\section{CG, MCG 및 WPMCG의 ginsenosides 함량}

$\mathrm{CG}, \mathrm{MCG}$ 및 $\mathrm{WPMCG}$ 의 ginsenosides 함량을 분석한 결과 Table 4 및 Fig. 2와 같았다. 총 ginsenosides 함량은 WPMCG (42.44) > MCG (18.01)> CG (14.31 mg/g) 순으로 $\mathrm{CG}$ 대비 $\mathrm{WPMCG}$ 에서 약 3 배의 함량이 검출되었다. 한편, WPMCG는 $\mathrm{CG}$ 와 $\mathrm{MCG}$ 에서는 검출되지 않는 희귀 ginsenosides $\mathrm{F} 5, \mathrm{~F} 3$, $\mathrm{F} 1, \mathrm{Rd}$ 및 $\mathrm{Rh} 2$ 가 검출되었다. 특히, $\mathrm{MCG}$ 는 인체흡수가 용이 한 ginsenoside $\mathrm{Rd} 2(1.36 \mathrm{mg} / \mathrm{g})$ 의 함량이 높았고, WPMCG는 단일 화합물로 $\mathrm{Re}$ 함량이 $7.78 \mathrm{mg} / \mathrm{g}$ 로 $\mathrm{CG}(1.78 \mathrm{mg} / \mathrm{g})$ 및
MCG $(2.53 \mathrm{mg} / \mathrm{g})$ 와 비교해 최대 4.4배 높게 검출되었다. 그 밖 에도 인체흡수가 용이한 ginsenosides $\mathrm{Rd}, \mathrm{Rd} 2$ 및 F2 (4.48, 3.78 및 $4.01 \mathrm{mg} / \mathrm{g}$ ) 함량이 $\mathrm{CG}$ 와 $\mathrm{MCG}$ 보다 월등히 높게 검출 되었다.

Jeong 등[37]은 ginsenosides Rb1, Rc, Rd, Rf, Rg1과 Rh1 이 4년근 인삼 $>6$ 년근인삼 > 산양삼 순을 나타내는 것으로 보 고해 본 연구와는 상이하였으며, $\mathrm{Rb} 2$ 및 $\mathrm{Re}$ 는 4년근 인삼 > 산 양삼 $>6$ 년근 인삼 순으로 보고해 본 연구에서 동일한 년근의 $\mathrm{CG}$ 및 $\mathrm{MCG}$ 의 결과와는 상이하였다. Ginsenoside $\mathrm{Rg} 3$ 함량의 경우 산양삼에서 미량 검출되었으나 4년근 및 6 년근 인삼에서 불검출로 보고하여 본 연구와 같은 결과를 보였다. Kim 등[38] 은 총 ginsenosides 함량이 지하부에 비해 지상부에서 높은 것 으로 보고하였으며 ginsenosides $\mathrm{Rg} 3, \mathrm{Rh} 2$ 및 compound $\mathrm{K}$ 또한 지상부에서 높게 확인되어, 본 연구의 $\mathrm{WPMCG}$ 와 동일한 결과를 나타내었다. 
(A)

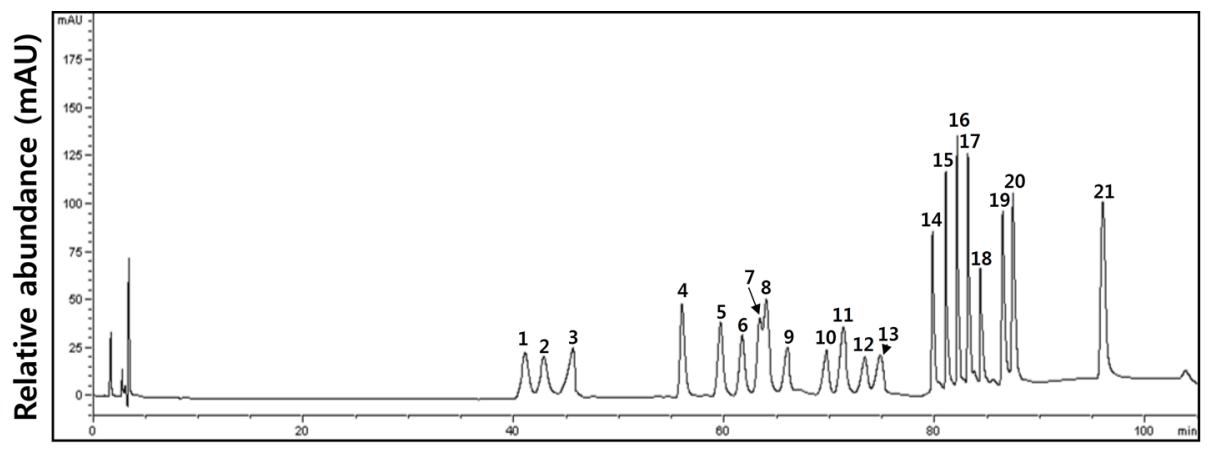

(B)

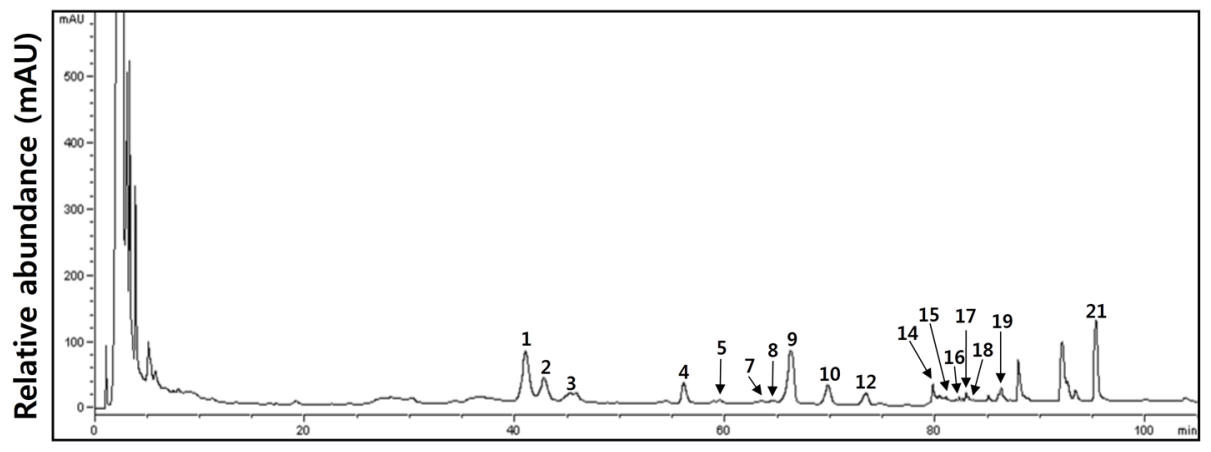

(C)

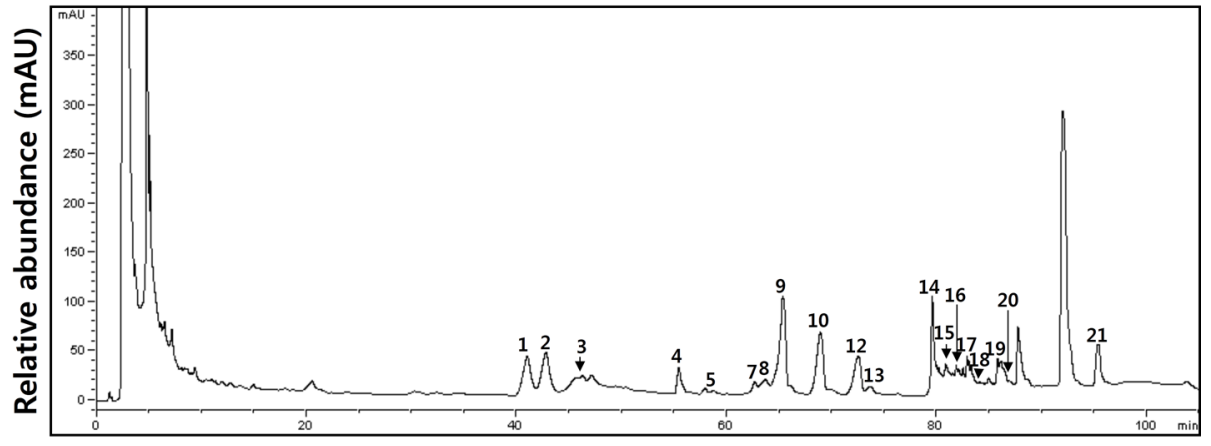

(D)

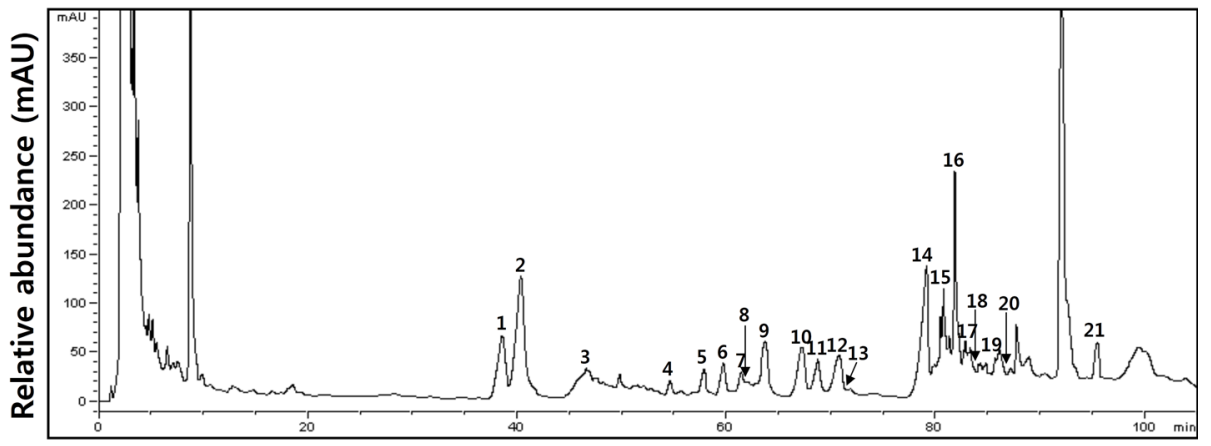

Retention time (min)

Fig. 2 Typical ginsenosides HPLC chromatogram of the $50 \%$ methanol extracts of total phenolic and total flavonoid contents on cultivated ginseng, mountain-cultivated ginseng, and whole plant of mountain-cultivated ginseng. (A) Standards; (B) $50 \%$ methanol extracts of cultivated ginseng; (C) $50 \%$ methanol extracts of mountain-cultivated ginseng; and (D) 50\% methanol extracts of whole plant of mountain-cultivated ginseng. 1: ginsenoside Rg1, 2: ginsenoside Re, 3: ginsenoside Ro, 4: ginsenoside Rf, 5: ginsenoside F5, 6: ginsenoside F3, 7: ginsenoside Rg2, 8: ginsenoside Rh1, 9: ginsenoside Rb1, 10: ginsenoside Rc, 11: ginsenoside F1, 12: ginsenoside Rb2, 13: ginsenoside Rb3, 14: ginsenoside Rd, 15: ginsenoside Rd2, 16: ginsenoside F2, 17: ginsenoside Rg3, 18: protopanaxtriol (PPT), 19: compound K (CK), 20: ginsenoside Rh2, and 21: protopanaxdiol (PPD) 

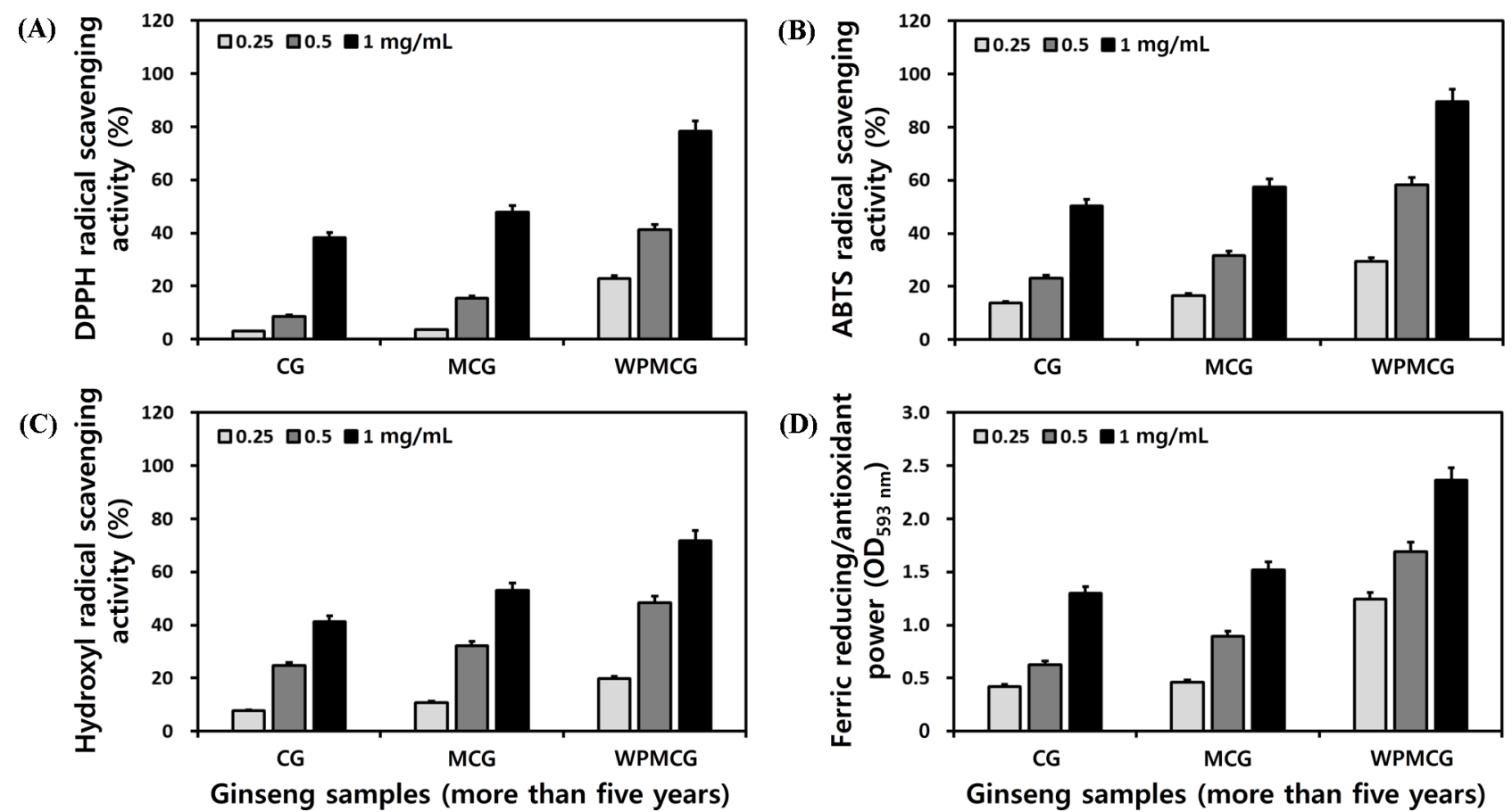

Fig. 3 Comparison of antioxidant effects on cultivated ginseng, mountain-cultivated ginseng, and whole plant of mountain-cultivated ginseng. (A) DPPH radical scavenging activity; (B) ABTS radical scavenging activity; (C) hydroxyl radical scavenging activity; and (D) ferric reducing/antioxidant power. All values are present as the mean $\pm \mathrm{SD}$ of triplicate determination

\section{CG, MCG 및 WPMCG의 항산화 활성}

$\mathrm{CG}, \mathrm{MCG}$ 및 $\mathrm{WPMCG}$ 의 $\mathrm{DPPH}, \mathrm{ABTS}$, hydroxyl 라디칼 소 거활성 및 FRAP 환원력을 비교한 결과 Fig. 3과 같았다. 모든 항산화 활성은 시료 $0.25,0.5$ 및 $1 \mathrm{mg} / \mathrm{mL}$ 의 농도를 처리하여 확인하였다. DPPH 라디칼 소거활성 분석결과 모든 농도에서 $\mathrm{WPMCG}>\mathrm{MCG}>\mathrm{CG}$ 순으로 $\mathrm{WPMCG}$ 에서 가장 높은 활성을 나타내었다. $1 \mathrm{mg} / \mathrm{mL}$ 처리 시 $\mathrm{CG}$ MCG 및 WPMCG 각각 $38.32,47.82$ 및 $78.29 \%$ 의 활성을 나타내어 $\mathrm{CG}$ 및 $\mathrm{MCG}$ 와 비교하여 $\mathrm{WPMCG}$ 에서 많게는 2 배 높은 활성이 나타났다. $\mathrm{ABTS}$ 라디칼 소거활성을 측정한 결과 시료 농도가 증가함에 따라 라디칼 소거활성이 증가하며 모든 농도에서 $\mathrm{WPMCG}>$ $\mathrm{MCG}>\mathrm{CG}$ 으로 $\mathrm{DPPH}$ 라디칼 소거활성 결과와 마찬가지로 $\mathrm{WPMCG}$ 에서 가장 높은 활성을 보였으며 전체적으로는 $\mathrm{DPPH}$ 보다 $\mathrm{ABTS}$ 에서 높은 소거활성을 보였다. 시료 $1 \mathrm{mg} / \mathrm{mL}$ 농도 처리시 $\mathrm{CG}$ 와 $\mathrm{MCG}$ 는 각각 $50.37 \%$ 와 $57.49 \%$ 결과를 보였고 WPMCG는 $89.73 \%$ 활성도를 나타내며 약 1.5 배 이상의 높은 소거활성을 나타냈다. Hydroxyl 라디칼 소거활성을 측정한 결 과 $1 \mathrm{mg} / \mathrm{mL}$ 처리 시 $\mathrm{CG}$ MCG 및 $\mathrm{WPMCG}$ 에서 각각 41.28 , 43.17 와 $71.87 \%$ 으로 $\mathrm{CG}$ 에서 가장 낮은 소거활성을 나타냈으며 $\mathrm{DPPH}$ 및 hydroxyl 라디칼 소거활성과 유사한 결과를 나타내었 다. $\mathrm{FRAP}$ 환원력을 확인한 결과 $\mathrm{CG}$ 에서 가장 낮은 환원력을 보였고, 시료 $1 \mathrm{mg} / \mathrm{mL}$ 처리 시 $\mathrm{WPMCG}$ 에서 $2.365 \mathrm{OD}_{593} \mathrm{~nm}$ 의 환원력을 나타내어 CG (1.296) 및 MCG (1.516)와 비교해 약 1.5 배 높은 환원력을 보였다. 항산화 활성 분석결과 공통적 으로 $\mathrm{WPMCG}>\mathrm{MCG}>\mathrm{CG}$ 순으로 소거활성을 보였으며, $\mathrm{ABTS}>\mathrm{DPPH}>$ hydroxyl $>$ FRAP 순으로 확인되었다.
Park[39]은 새싹삼의 총 폴리페놀 및 총 플라보노이드 함량 이 항산화 활성 측정 결과와 유사하다고 보고하였으며, $\mathrm{Kim}$ 등 [38]은 새싹인삼의 총 phenolics와 총 flavonoids 함량이 항산화 활성과 유사한 결과를 나타내며 polyphenol성 화합물이 항산화 활성에 영향을 미치는 것으로 보고해 본 연구와 유사한 결과 보였다. $\mathrm{DPPH}$ 는 음이온 라디칼을 소거하는 활성을 확인하는 방법으로 진한 자색을 띄는 비교적 안정적인 자유라디칼로 황 을 함유한 아미노산과 L-ascorbic acid 등에 의해 환원되어 항 산화력을 확인하는 방법이며, $\mathrm{ABTS}$ 는 양이온 라디칼을 소거하 는 활성능을 확인하는 방법으로 hydroxyl, peroxyl, alkoxyl 및 inogranic radical과 반응해 안정적인 양이온 라디칼을 형성시켜 친수성과 소수성 물질의 항산화 측정이 가능하다 $[40,41]$. Hydroxyl 라디칼 소거활성은 fenton system $\left(\mathrm{Fe}^{3+}\right.$-ascorbateEDTA- $\mathrm{H}_{2} \mathrm{O}_{2}$ )으로 생성되는 hydroxyl 라디칼을 소거하는 활성을 확인하는 방법이다[42]. FRAP 환원력은 $\mathrm{Fe}^{3+}$ 가 수소를 공여 받 아 라디칼이 안정화되어 $\mathrm{Fe}^{2+}$ 로 환원되는 것을 이용하는 방법 이다[39]. 따라서 ABTS는 DPPH, hydroxyl 및 FRAP 환원력 에 비해 다양한 항산화물질과 반응하여 다른 라디칼 소거활성 에 비해 높은 소거활성을 보이는 것으로 판단된다.

$\mathrm{CG}, \mathrm{MCG}$ 및 $\mathrm{WPMCG}$ 를 비교 분석한 결과 ginsenosides 및 항산화 활성은 대부분 $\mathrm{WPMCG}$ 에서 높게 나타났으며, 이는 $\mathrm{CG}$ 및 $\mathrm{MCG}$ 에는 포함되어 있지 않은 잎과 줄기의 성분에 의 한 것으로 예상되어 이후 잎, 줄기 및 뿌리 부위에 따른 연구 가 필요할 것으로 판단된다. 
초 록

5년근 이상의 인삼(CG), 산양삼(MCG) 및 산양삼 전초(WPMCG) 의 지방산, 아미노산, 무기질, ginsenosides, 총 phenolics, 총 flavonoids 및 항산화 활성을 비교하여 분석하였다. 총 지방산 및 불포화 지방산 함량은 MCG (1215.9 및 $751.2 \mathrm{mg} / 100 \mathrm{~g})$ 에 서, 포화 지방산은 WPMCG $(486.4 \mathrm{mg} / 100 \mathrm{~g})$ 에서 각각 높았으 며 $\alpha$-linolenic acid 함량은 특징적으로 CG $(18.1 \mathrm{mg} / 100 \mathrm{~g})$ 에 비해 MCG (139.3 mg/100 g) 및 WPMCG (194.4 mg/100 g)에 서 최대 10 배 높게 검출되었다. 총 유리아미노산 및 필수 아미 노산 함량은 $\mathrm{CG}<\mathrm{MCG}<\mathrm{WPMCG}(1006.35$ 및 $839.46 \mathrm{mg}$ / $100 \mathrm{~g})$ 순으로 높았으며, $\gamma$-aminobutyric acid 및 arginine이 주 된 비필수 아미노산으로 각각 WPMCG $(163.10 \mathrm{mg} / 100 \mathrm{~g})$ 와 $\mathrm{MCG}(305.23 \mathrm{mg} / 100 \mathrm{~g})$ 에서 가장 높게 검출되었다. 총 무기질 함량은 CG $(30.36 \mathrm{mg} / 100 \mathrm{~g})$ 와 WPMCG $(29.82 \mathrm{mg} / 100 \mathrm{~g})$ 에서 높게 검출되었으며, 칼슘 $(\mathrm{Ca})$ 은 $\mathrm{CG}$ 및 $\mathrm{MCG}$ 와 비교하여 WPMCG $(6.68 \mathrm{mg} / 100 \mathrm{~g})$ 에서 약 2배 이상의 높게 검출되었다. 총 phenolics (5.12 GAE mg/g), 총 flavonoids (3.04 RE mg/g) 및 ginsenosides $(42.44 \mathrm{mg} / \mathrm{g})$ 함량은 $\mathrm{WPMCG}$ 에서 공통적으로 가장 높은 함량이 검출되었으며 이와 유의적으로 항산화 활성 역시 $\mathrm{WPMCG}$ 에서 가장 높은 활성을 나타내었다.

Keywords 산양삼 - 아미노산 · 지방산 - 진세노사이드 · 항산화

감사의 글 본 연구는 산림청과 한국임업진흥원의 산림생명소재 발굴사업 (Project No. 2017023A001919BA01 \& 2020187A002002BA01)에 지원에 이 루어진 결과입니다.

\section{References}

1. Kim MW, Lee EH, Kim YJ, Park TS, Cho YJ (2018) Beauty food activities of wild-cultivated Ginseng (Panax ginseng C.A. Meyer) ground part. J Appl Biol Chem 61: 33-38. doi: 10.3839/jabc.2018.005

2. Leea JH, Kim SC, Lee HY, Cho DY, Jung JG, Kang D, Kang SS, Cho KM (2021) Changes in nutritional compositions of processed mountaincultivated ginseng sprouts (Panax ginseng) and screening for their antioxidant and anti-inflammatory properties. J Funct Food 86: 104668. doi: 10.1016/j.jff.2021.104668

3. Kim KY, Um YR, Jeong DH, Kim HJ, Kim MJ, Jeon KS (2019) The correlation between growth characteristics and location environment of wild-simulated ginseng (Panax ginseng C.A. Meyer). Korean J Plant Res 32: $463-470$

4. Nah SY (1997) Ginseng; Recent advances and trends. Korean J Ginseng Sci 21: 1-12

5. Kim MW, Ko SR, Choi KJ, Kim SC (1987) Distribution of saponin in various sections of Panax ginseng root and changes of its contents according to root age. Korean J Ginseng Sci 19: 10-16

6. Park JD (1996) Recent studies on the chemical constituents of Korean ginseng (Panax ginseng C.A Meyer). Korean J Ginseng Sci 20: 389-415

7. Kang KM, Lee JY, Kim MU, Lee SH (2016) Effect of quality characteristics and antioxidant activity of Korean cultivated wild ginseng extract. J Korean Soc Food Sci Nutr 45: 1740-1746

8. Lee G, Choi GS, Lee JY, Yun SJ, Kim WK, Lee HJ, Baik MY, Hwang JK (2017) Proximate analysis and antioxidant activity of cultivated wild Panax ginseng. Food Eng Prog 21: 208-214. doi: 10.13050/ foodengprog.2017.21.3.208

9. Kim SJ, Shin SS, Seo BI, Jee SY (2004) Effect of mountain grown ginseng radix, mountain cultivated ginseng radix, and cultivated ginseng radix on apoptosis of HL-60 cells. Korea J Herb 19: 41

10. Kim EL, Kim CS, Lee HY, Lee HR, Kim EY, Yoon MC, Shin SS (2012) Mountain cultivated ginseng water boiled extract decreases blood glucose level and improves lipid metabolism in male $d b / d b$ mice. Korea J Herb 27: 69-75. doi: 10.6116/kjh.2012.27.2.69

11. Lee G, Na GH, Kim WK, Baik MY, Lee HJ, Hwang JK (2017) Antiinflammatory effect of cultivated wild Panax ginseng extracts at various ages in RAW 264.6 macrophages. Food Eng Prog 21: 201-207

12. Kwon SJ, Chung DK (2004) The immune-enhancing effect of mountain gown ginseng, mountain cultivated ginseng, and Panax ginseng. J Oriental Neuropsychiatry 15: 89-101

13. Jung JI, Kim JM, Kim HS, Kim HS, Kim EJ (2019) Immunostimulatory effect of wild-cultivated ginseng extract via the increase in phygocytosis and cytokine secretions in RAW 264.7 macrophages. J Korean Soc Food Sci Nutr 48: 686-691

14. Lee HU, Bae EA, Han MJ, Kim DH (2005) Hepatoprotective effect of 20(S)-ginsenosides $\mathrm{Rg} 3$ and its metabolite 20(S)-ginsenoside $\mathrm{Rh} 2$ on tert-butyl hydroperoxide-induced liver injury. Biol Pharm Bull 28: 1992 1994

15. Lui JHC, Staba EJ (1980) The ginsenosides of various ginseng plants and selected products. J Nat Prod 43(3): 340-346. doi: 10.1021/ np50009a004

16. Hwang SH, Kim SC, Seong JA, Lee HY, Cho DY, Kim MJ, Jung JG, Jeong EH, Son KH, Cho KM (2021) Comparison of ginsenoside contents and antioxidant activity according to the size of ginseng sprout has produced in a plant factory. J Appl Biol Chem 64: 253-261

17. Jung BK, Jung KR, Kim MS, Moon HG, Park SJ, Chun JY (2019) Ginsenoside contents and antioxidant activities of cultivated mountain ginseng (Panax ginseng C.A. Meyer) with different ages. Korean J Food Preserv 26: 90-100

18. Park H (2019) The role of gut nicrobiota in ginsenoside metabolism and biotransformation of ginsenoside by lactic acid bacteria. Curr Top Lact Acid Bact Probiotics 5: 1-12

19. Zhou P, Xie W, He S, Sun Y, Meng X, Sun G, Sun X (2019) Ginsenoside $\mathrm{Rb} 1$ as an anti-diabetic agent and its underlying mechanism analysis. Cells 8: 204

20. Seo BY, Choi MJ, Kim JS, Park EJ (2019) Comparative analysis of ginsenoside profiles: Antioxidant, antiproliferative, and antigenotoxic activities of ginseng extracts of fine and main roots. Prev Nut Food Sci 24: 128-135. doi: 10.3746/pnf.2019.24.2.128

21. Kim NE, Lee MO, Jang MH, Chung BH (2018) Angiogenic effects of wood-cultivated ginseng extract and ginsenoside $\mathrm{Rg} 5$ in human umbilical vein endothelial cells. Korean J Food Sci Technol 50: 349355. doi: 10.9721/KJFST.2018.50.3.349

22. Shin SW, Lee JA, Son DH, Park DH, Jung ES (2017) Anti-skin-aging activity of a standardized extract from Panax ginseng leaves in vitro and in human volunteer. J Cosmetics 4: 18. doi: 10.3390/cosmetics4020018

23. Lee HY, Lee DH, Kim SC, Cho DY, Cho KM (2020) Changes in nutritional components and antioxidant activities from soybean leaves containing high isoflavone contents according to different storage temperatures and periods. J Appl Biol Chem 63: 305-317. doi: 10.3839/ jabc.2020.041

24. Ministry of food and drug safety (1999) http://www.foodsafetykorea.go.kr/ foodcode/01_01.jsp Accessed 12 Nov 1999

25. Singleton VL, Rossi JA (1965) Colorimetry of total phenolics with phosphomolybdic-phosphotungstic acid reagents. Am J Enol Vitic 16: 144-158

26. Park YJ, Lee JM, In MJ, Chae HJ (2020) Optimization of extraction conditions of flavonoid compounds from Thyme (Thymus vulgaris Libiatae). J Appl Biol Chem 63: 111-116. doi: 10.3839/jabc.2020.015

27. Hwang CE, Kim SC, Lee JH, Hong SY, Cho KM (2018) Enhanced biological effect of fermented soy-powder milk with Lactobacillus brevis increasing in $\gamma$-aminobutyric acid and isoflavone aglycone contents. J Appl Biol Chem 61: 245-255 
28. Park CK, Jeon BS, Yang JW (2003) The chemical components of Korean ginseng. Food Industry and Nutrition. 8: 10-23

29. Kim JH, Kim JK (2006) Antioxidant activity and functional component analysis of korean mountain ginseng's different sections. J Korean Soc Food Sci Nutr 35: 1315-1321. doi: 10.3746/jkfn.2006.35.10.1315

30. Ko YS, Chung BS (1981) Studies on the oil soluble constituents of Korean ginseng ?. On the fatty acid composition determined by HPLC. Korean J Food Sci Technol 13: 15-19

31. Choi JH, Oh SK (1985) Studies on the anti-aging action of Korean ginseng. Korean J Food Sci Technol 17: 506-515

32. Ko SR, Choi KJ, Han KW (1996) Comparison of proximate composition, mineral nutrient, amino acid and free sugar contents of several Panax species. Korean J Ginseng Sci 20: 36-41

33. Kang KM, Lee JY, kim MU, Lee SH (2016) Effects of quality characteristics and antioxidant activity of korean cultivated wild ginseng extract. J Korean Soc food Sci Nutr 45: 1740-1746. doi: 10.3746/ jkfn.2016.45.12.1740

34. Lee JW, Lee SK, Do JH (2002) Comparison of the content of saponin and mineral component in Korean red ginseng and other red ginseng. $\mathrm{J}$ Ginseng Res 26: 196-201. doi: 10.5142/JGR.2002.26.4.196

35. Han JH, Park SJ, Ahn JM, Wee JJ, Kim KY, Park SH (2004) Nutritional composition, ginsenoside content and fundermental safety evaluation with leaf and steam extract of Panax ginseng. J Korean Soc Food Sci Nutr 33: 778-784

36. Shin YA (2016) Effect of physical activity, and sodium and potassium intakes on blood pressure and obesity. Korean Soc for Wellness 11: 409_ 423

37. Jeong HS, Kim CS, Cha BC, Choi SH, Kwon KR (2010) Component analysis of cultivated ginseng, cultivated wild ginseng, and wild ginseng and the change of ginsenoside components in the process of red ginseng. Journal of Pharmacopuncture Institute 13: 63-77. doi: 10.3831/ KPI.2010.13.1.063

38. Kim SC, Kang YM, Seong JA, Lee HY, Cho DY, Joo OS, Lee JH, Cho KM (2021) Comprehensive changes of nutritional constituents and antioxidant activities of ginseng sprouts according to the roasting process. Korean J Food Preserv 28: 72-87. doi: 10.11002/kjfp.2021. 28.1.72

39. Park SJ (2019) Antioxidant activities and whitening effects of ethanol extract from Panax ginseng sprout powder. J Korean Soc Food Sci Nutr 48: 276-281

40. Re R, Pellegrini N, Proteggente N, Pannala A, Yang M, Rice-Evans C (1999) Antioxidant activity applying an improved ABTS radical cation decolorization assay. Free Radical Bio Med 26: 1231-1237

41. Lee SO, Kim MJ, Lim DG, Choi HJ (2005) Antioxidative activities of temperature-stepwise water extracts from Inonotus obliquus. J Korean Soc Food Sci Nutr 34: 139-147. doi: 10.3746/jkfn.2005.34.2.139

42. Rhim TJ, Jeong HS, Kim YJ, Kim DY, Han YJ, Kwon HY, Kwon KR (2009) A study on the comparison of antioxidant effects among cultivated ginseng and cultivated wild ginseng extracts. Journal of pharmacopuncture Institute 12: 7-12. doi: 10.3831/KPI.2009.12.2.007 